\title{
大腸 $\mathrm{mp}$ 癌の発育形態とリンパ節, 血行性転移 \\ 一画像解析を用いて一
}

\begin{tabular}{|c|c|c|c|c|c|c|}
\hline \multicolumn{7}{|c|}{ 東海大学医学部第 2 外科 } \\
\hline 貞廣荘太郎 & 向井 & 正哉 & 石田 & 秀樹 & 徳永 & 信弘 \\
\hline 木村 富彦 & 鈴木 & 俊之 & 岩瀬 & 弘忠 & 石川 & 健 \\
\hline 島 知郎 & 三富 & 利夫 & & & & \\
\hline
\end{tabular}

大腸癌の転移の危険因子を検索する目的で, 大腸 $\mathrm{mp}$ 癌 102 例を対象に癌腫の最大割面における腫瘍 の発育形態，浸潤深度を画像解析装置を用いて分析した． 1 型の腫湯は 2 型の腫場に比べ $\mathrm{m}$ 層での腫

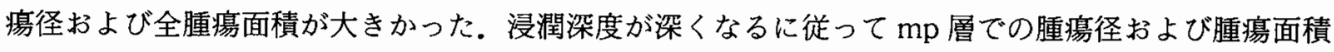
は増加したが, $\mathrm{m}$ 層での腫瘍径および全腫瘍面積には差がなかった.すなわち $\mathrm{mp}$ 癌において腫瘍径 と浸潤深度に関連性は認められなかった。リンパ節転移の有無で発育形態に差はみられなかったが, 血行性転移陽性例では陰性例に比べ, $\mathrm{mp}$ 層の腫腸面積は小さく $(\mathrm{p}=0.018)$, 全腫場面積に占める $\mathrm{mp}$ 層の腫汮面積の比率も小さかった $(\mathrm{p}=0.0005)$. 血行性転移の頻度は浸潤深度が深いほど減少したが 有意の関係ではなかった.

以上から, 組織標本の上での浸潤の程度, 樑度から転移を予測することは困難であり, 浸潤程度が 軽度である症例でも血行性転移の頻度は低くないことを認識する必要がある。

Key words: colorectal cancer, image analysis, lymph node metastasis, hematogenous metastasis

はじめに

大腸癌の浸潤が粘膜下層に達した大腸 $\mathrm{sm}$ 癌と固有 筋層に達した大腸 $\mathrm{mp}$ 癌は早期癌と進行癌の境界をな しており，大腸癌の転移の危険因子を検索する対象と して適していると考えら机る. 今回大腸 $\mathrm{mp}$ 癌症例を 対象として, 従来からの組織学的因子に加え, 癌腫の 最大割面における腫瘍の発育形態, 浸潤深度を画像解 析装置を用いて分析し，転移の危険因子を検索した，

\section{研究対象ならびに研究方法}

1979年から1992年までに経験した原発性大腸癌は 1,014例で, 壁深達度が固有筋層であった $\mathrm{mp}$ 癌は 106 例 $(10.5 \%)$ であった. $\mathrm{mp}$ 癌は結腸癌581例中37例 $(6.4 \%)$, 直腸癌 416 例中 69 例（16.6\%）に相当し，直 腸癌では結腸癌に比べ $\mathrm{mp}$ 癌の頻度が高率であった $(\mathrm{p}<0.001)$.これらのうち手術後 2 年以上追跡調査が 可能であった102例を研究対象とした。術後の追跡期間 は24〜234か月（平均77士48か月）であった。

手術時にリンパ節に転移がみられた32例をリンパ節

$<1996$ 年 10 月 9 日受理 $>$ 別刷請求先 : 貞廣荘太郎 T259-11 伊勢原市望星台 東海大学医学部第 2 外科
転移陽性群，リンパ節に転移がみられなかった69例を リンパ節転移陰性群とした。

また, 手術時に肝転移がみられた 5 例と手術後の追 跡期間中に肝臓，肺，脳，骨に転移がみられた 4 例を 合わせて血行性転移陽性群, 残りの93例を血行性転移 陰性群とした。

癌腫の最大割面の $\mathrm{H} \cdot \mathrm{E}$ 標本において, 従来の組織 型, 脈管侵襲などの因子に加えて, コンピューターイ メージ解析装置 (VIDAS, Carl Zeiss, Germany) を 用いて粘膜層 ( $\mathrm{m}$ 層) での最大径 (length-m), 固有筋 層 (mp 層) での最大径 (length-mp), 全腫瘍面積 (area-total), mp 層での腫場面積（area-mp）を測定 $し$, length-mp/length-m 比率およぴ area-mp/areatotal 比率を算出した (Fig. 1).さらに mp 層内の浸潤 深度を坂谷らの分類 ${ }^{1}$ に従って, $\mathrm{mp}_{1}$ (固有筋層のうち 内輪筋の内腔側 $1 / 2$ までの浸潤), $\mathrm{mp}_{3}$ (固有筋層のうち 外縦筋に至る浸潤), および $\mathrm{mp}_{2}\left(\mathrm{mp}_{1}\right.$ と $\mathrm{mp}_{3}$ の中間) の 3 段階に分類した。これらの腫瘍の発育形態と浸潤 深度の評価項目を従来の組織学的因子と対比し, 転移 の危険因子を検索した.なお使用する臨床病理学的用 語は大腸癌取扱い規約 ${ }^{21}$ に準じ, 推計学的検定には $\chi^{2}$. 
Fig. 1 Measurment of growth appearance using the image analyzer

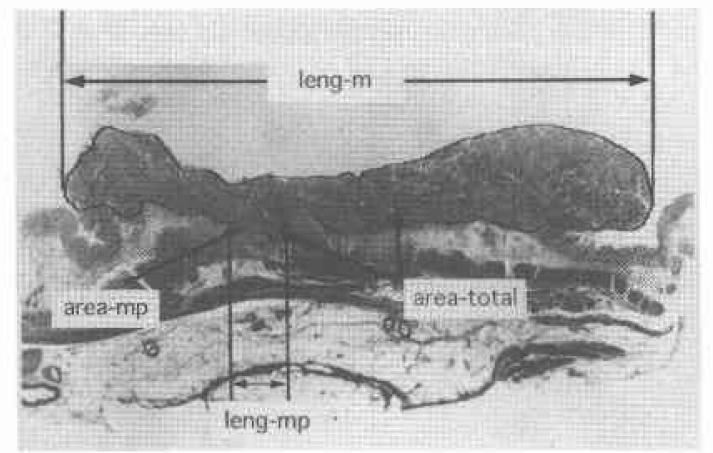

test あるいは Student-t test を用いた。

\section{結 果}

最大割面での発育形態：癌腫の腫瘍径は占居部位が 結腸と直腸とで差はなかったが, 直腸の $\mathrm{mp}$ 癌は結腸 の mp 癌に比べ, 全腫演面積は小さかった(Table 1). 肉眼形態が 1 型の腫瘍は 2 型の腫湯に比べ $\mathrm{m}$ 層での 腫瘍径および全腫湟面積が大きかったが，mp 層内で
の腫瘍径および腫瘍面積には差がなかった，浸潤深度 が深くなるに従って mp 層での腫瘍径および腫瘍面積 は増加したが， $m$ 層での腫場径および全腫瘍面積には 差がなかった。すなわち, $m p$ 癌においいては腫瘍の大き さと浸潤深度に関連性は認められなかった。また組織 型, リンパ節転移の有無, リンパ管侵襲の有無, 静脈 侵襲の有無と発育形態との間には関連性は認められな かった。

リンパ節転移の有無で発育形態を比較した（Table 2).腫瘍径は $\mathrm{m}$ 層および $\mathrm{mp}$ 層いずれにおいてもりン パ節転移陽性群および陰性群の間に差はなかった。全 腫瘍面積, $\mathrm{mp}$ 層の腫瘍面積にも, 両群間に差はみられ なかった。

血行性転移の有無で発育形態を比較した（Table 2).腫瘍径は $\mathrm{m}$ 層および $\mathrm{mp}$ 層いずれにおいても血行 性転移陽性群および陰性群の間に差はなかった。全腫 瘍面積には兩群間に差はみられなかったが, mp 層の 腫湟面積は陽性群は陰性群に比べ有意に小さく（ 0.018), 全腫瘍面積に占める $\mathrm{mp}$ 曆の腫瘍面積の比率 も, 陽性群は陰性群に比べ有意に小さかった $(\mathrm{p}<$

Table 1 Image analyzer studies on tumor growth in relation to tumor site, macroscopic appearance and degree of invsion

\begin{tabular}{|c|c|c|c|c|c|c|c|}
\hline & $\mathrm{N}$ & leng-m & leng-mp & $\begin{array}{l}\text { leng-mp/ } \\
\text { leng-m }\end{array}$ & area-total & area-mp & $\begin{array}{l}\text { area-mp/ } \\
\text { area-total }\end{array}$ \\
\hline colon & 35 & $33 \pm 16$ & $13 \pm 9$ & $41 \pm 23^{11}$ & $220 \pm 180$ & $41 \pm 62$ & $18 \pm 17^{13}$ \\
\hline rectum & 67 & $30 \pm 15$ & $12 \pm 8$ & $42 \pm 19$ & $153 \pm 152$ & $21 \pm 21$ & $17 \pm 11$ \\
\hline type 1 & 24 & $37 \pm 23$ & $11 \pm 9$ & $31 \pm 24$ & $303 \pm 258$ & $37 \pm 72$ & $12 \pm 167 *$ \\
\hline type 2 & 70 & $28 \pm 10$ & $13 \pm 8$ & $46 \pm 19$ & $126 \pm 72 \quad J^{2 / 3}$ & $24 \pm 22$ & $20 \pm 12]^{*}$ \\
\hline $\mathrm{mp} 1$ & 29 & $33 \pm 21$ & $8 \pm 7$ 고 & $26 \pm 19$ 고 & $210 \pm 222$ & $11 \pm 12$ & $7 \pm 6$ \\
\hline $\mathrm{mp} 2$ & 50 & $29 \pm 11$ & $13 \pm 7=*$ 级 & $45 \pm 18$ - & $150 \pm 114$ & $30 \pm 47-$ 极 & $20 \pm 12$ \\
\hline $\mathrm{mp} 3$ & 23 & $32 \pm 15$ & $17 \pm 9-{ }^{*}$ & $53 \pm 17$ & $189 \pm 169$ & $46 \pm 43$ & $24 \pm 15$ \\
\hline
\end{tabular}

leng-m: tumor length in mucosa (mm), length-mp : tumor length in muscularis propria (mm), area-total : total tumor area $\left(\mathrm{mm}^{3}\right)$, area-mp : tumor area in muscularis propria $\left(\mathrm{mm}^{3}\right)$

1) :\%

Table 2 Image analyzer studies on tumor growth in relation to lymph node metastasis

\begin{tabular}{c|c|c|c|c|c|c}
\hline \multirow{2}{*}{} & \multicolumn{2}{|c|}{ lymph node metastasis } & \multirow{2}{*}{ p-value } & \multicolumn{2}{c|}{ hematogeous metastasis } & \multirow{2}{*}{ p-value } \\
\cline { 2 - 3 } & positive & negative & & poisitive & negative & \\
\hline leng-m $(\mathrm{mm})$ & $29 \pm 11$ & $32 \pm 17$ & 0.3 & $30 \pm 10$ & $31 \pm 15$ & 0.9 \\
leng-mp $(\mathrm{mm})$ & $12 \pm 8$ & $13 \pm 9$ & 0.8 & $12 \pm 5$ & $13 \pm 9$ & 0.8 \\
leng-mp/leng-m(\%) & $42 \pm 17$ & $41 \pm 23$ & 0.8 & $39 \pm 13$ & $42 \pm 22$ & 0.7 \\
area-total $\left(\mathrm{mm}^{2}\right)$ & $152 \pm 123$ & $185 \pm 172$ & 0.3 & $154 \pm 71$ & $175 \pm 163$ & 0.5 \\
area-mp $\left(\mathrm{mm}^{2}\right)$ & $29 \pm 56$ & $28 \pm 34$ & 0.9 & $16 \pm 9$ & $29 \pm 43$ & 0.02 \\
area-mp/area-total(\%) & $19 \pm 13$ & $17 \pm 14$ & 0.5 & $10 \pm 4$ & $18 \pm 14$ & $\mathrm{p}<0.01$ \\
\hline
\end{tabular}


Table 3 Image analyzer studies on tumor growth in relation to hematogenous metastasis

\begin{tabular}{|c|c|c|c|c|c|c|}
\hline & \multicolumn{2}{|c|}{ lymph node metastasis } & \multirow{2}{*}{ p-value } & \multicolumn{2}{|c|}{ hematogeous metastasis } & \multirow{2}{*}{ p-value } \\
\hline & poisitive & negative & & positive & negative & \\
\hline \multicolumn{7}{|l|}{ tumor site } \\
\hline Colon & 10 & 24 & 0.9 & 4 & 31 & 0.8 \\
\hline Rectum & 22 & 45 & & 5 & 62 & \\
\hline \multicolumn{7}{|l|}{ macroscopic appearance } \\
\hline type 1 & 6 & 18 & & 1 & 23 & \\
\hline type 2 & 24 & 45 & 0.6 & 8 & 62 & 0.4 \\
\hline type 3 & 2 & 6 & & 0 & 8 & \\
\hline \multicolumn{7}{|l|}{ histology } \\
\hline well differentiated adenoca. & 14 & 41 & & 5 & 51 & \\
\hline moderate differentiated adenoca & 16 & 26 & 0.3 & 4 & 38 & 0.9 \\
\hline poorly differentiated adenoca. & 1 & 1 & & 0 & 2 & \\
\hline \multicolumn{7}{|l|}{ lymph node metstasis } \\
\hline positive & & & & 4 & 28 & 0.8 \\
\hline negative & & & & 4 & 65 & \\
\hline \multicolumn{7}{|l|}{ lymph vessel invasion } \\
\hline positive & 27 & 52 & 0.6 & 7 & 73 & 0.9 \\
\hline negative & 5 & 15 & & 1 & 19 & \\
\hline \multicolumn{7}{|l|}{ venous vessel invasion } \\
\hline positive & 23 & 36 & 0.1 & 5 & 55 & 0.9 \\
\hline negative & 9 & 31 & & 3 & 37 & \\
\hline \multicolumn{7}{|l|}{ degree of infiltration } \\
\hline $\mathrm{mp} 1$ & 5 & 247 & & $\overline{5}$ & 24 & \\
\hline mp 2 & 23 & $2 \tau \jmath$ & $\begin{array}{l}0.02 \\
0.03\end{array}$ & 3 & 47 & 0.2 \\
\hline $\mathrm{mp} 3$ & 4 & $18\lrcorner$ & 0.03 & 1 & 22 & \\
\hline
\end{tabular}

0.01).

リンパ節転移の有無, 血行性転移の有無と癌の占居 部位, 肉眼形態, 組織型, 脈管侵襲, 浸潤深度との関 連性について検索した（Table 3)。リンパ節転移の有 無が不明であった 1 例，脈管侵襲の有無が不明であっ た 3 例については, 当該項目は久損值として取り扱っ た。

リンパ節転移および血行性転移と癌の占居部位, 肉 眼形態, 組織型, 脈管侵襲の有無との間には関連性は みられなかった.リンパ節転移の頻度は, $\mathrm{mp}_{2}$ では $\mathrm{mp}_{1}$ および $\mathrm{mp}_{3}$ に比べ高率であり, 浸潤深度が深くなると リンパ節転移が増加することはなかった．血行性転移 の頻度は, $\mathrm{mp}_{1}$ で $17 \%, \mathrm{mp}_{2}$ で $6 \%, \mathrm{mp}_{3}$ で $4 \%$ と浸潤 深度が深いほど隇少したが有意の関係ではなかった。 リンパ節転移の有無と血行性転移の有無の間には関連 性はみられなかった。

\section{考察}

大腸 $\mathrm{mp}$ 癌が大腸癌全体に占める頻度については, 大腸癌研究会の全団集計によると, 結腸癌の $7.4 \%$, 直 腸癌の $18.8 \%$ と報告されており ${ }^{3)}$, 私達の結果でもお
のおの $7.4 \%, 16.8 \%$ で直腸癌で高頻度であった。この ように直腸癌で $\mathrm{mp}$ 癌の頻度が高い原因は, 下部直腸 においては, 固有筋層内輪筋層の厚さは他部位の約 2 倍, 外輪筋層の厚さは他部位の約 $3 \sim 4$ 倍であるため と考えられている4.

大腸癌の治癒切除後の予後不良因子として, リンパ 節転移陽性 ${ }^{5}$, リンパ節転移個数 ${ }^{6)}$, リンパ管侵襲7), 組 織型8), 壁深達度など9110)が報告されてきた。私達は対 象を壁深達度が固有筋層にとどまる腫瘍に限定して, 従来からの組織学的因子に加え, 癌の発育形態を最大 割面における腫瑒径, 腫場面積で評価して, 転移との 関連性を検索した。

$\mathrm{mp}$ 癌の腫瘍径については, 五十嵐ら ${ }^{11} は 34.4 \pm$

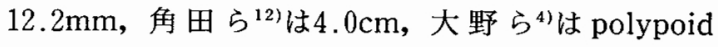
growth type では34.2mm, non polyoid growth type では30.3mm と本研究の結果に比べ若干大きな数値を 報告しているが, 腸管は切除固定後 $24 \sim 28 \%$ 収縮する こと ${ }^{13)}$ 考慮すると, 固定染色標本を用いた本研究の 結果はこれらの值とほほ一致するものと考えられた. $\mathrm{mp}$ 層内の浸潤深度に関しては, 坂谷の分類 ${ }^{1}$ に準じ 
て検討した．狩野らは浸潤が内輪筋にとどまる症例に 比へ，外縦筋に浸潤する症例では腫瘍径が大きいと報 告 ${ }^{14)}$ し, 横山らも深達度が深くなるに従って腫瘍径は

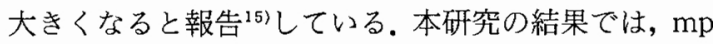
層内の浸潤深度と腫場径との間には関連性は認められ ず，大きな腫場ほど浸潤が深いとはいえなかった。最 大割面での画像解析の結果からは, 結腸の $\mathrm{mp}$ 癌は直 腸の $\mathrm{mp}$ 癌に比べ全腫瘍面積は大きく, 肉眼形態が 1

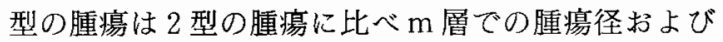
全腫瘍面積が大きいという特徵が明らかになった。

リンパ節転移陽性例と陰性例との比較では, リンパ 節転移と癌の発育形態, 浸潤深度とに関連性は認めら れなかったが, 血行性転移陽性例では陰性例に比べ, $\mathrm{mp}$ 層内の腫㰾面積が小さく, 浸潤深度が浅い傾向が みられた．現在までに $\mathrm{mp}$ 層内の浸潤面積と血行性転 移との関係は報告されていない. 神部らは深達度 ss, $\mathrm{a}_{1}$ 以上の大腸癌を対象として, 固有筋層穿破形態を分 析し, $\mathrm{mp}$ 層に入る部分の長さ $(\mathrm{A})$ と $\mathrm{ss}$ 層へ出る部分 の長さ（B）の比 A/B が血行性転移陽性例では陰性例 に比べ小さい，すなわち裾広がり傾向にあったと報告 している ${ }^{16)}$. 癌の浸潤の深さに加えて浸潤の形態を分 析し, 新しいパラメーターとしての可能性を検討した ものであるが，私達とは分析対象が異なっており，固 有筋層内の癌の面積を示す指標ではないため私達の結 果との比較は困難である。

癌の肉眼形態, 組織型, 脈管侵襲の有無とリンパ節 転移, 血行性転移との間には, 対象を大腸 $\mathrm{mp}$ 癌に限定 する限りにおいて関連性は認められなかった。した がって本研究の結果から, mp 癌において血行性転移 を伴う症例では，浸潤程度が軽度な症例にもすでに転 移が起こっており, 切除した組織標本の上での浸潤の 程度, 深度から転移扔よび予後を予測するためには何 らかの新しいパラメータが必要である。

\section{文献}

1）坂谷 新, 小泉浩一, 丸山雅一ほか：大腸 $\mathrm{sm}$ 癌の 診断, $\mathrm{x}$ 線診断の立場から. 胃と腸 $26: 726-$ 735,1991

2）大腸癌研究会編：大腸癌取扱い規約. 改訂第 5 版.
金原出版, 東京, 1994

3）小山靖夫, 固武健二郎：全国集計からみた大腸 $\mathrm{sm}$ 癌の現状. 胃と腸 $27: 1253-1529,1992$

4）大野直人, 下田忠和 : 大腸 pm 癌の病理学的検討, 進行癌における pm 癌の位置つ゚け。日本大腸肘門 病会誌 $46: 733-739,1993$

5）大木繁男, 嶋田 紘：リンパ節転移からみた直腸 pm 癌の治療方針. 胃と腸 $27: 1309-1313,1992$

6) Cohen AM, Tremiterra S, Candela F et al: Prognosis of node-positive colon cancer. Cancer $67: 1859-1861,1991$

7）白水和雄, 磯本浩晴, 諸富立寿ほか: 大腸癌のリン パ管侵襲, Prospective studyによる予後因子とし ての評価について. 日外会誌 $92 ： 1686-1693$, 1991

8）飯田 明：大腸癌の組織型と治療成績, とくに高 分化腺癌と中分化腺癌の生存率の違いについて。 日本大腸肛門病会誌 $43: 433-541,1990$

9) Rich $T$, Cunderson LL, Lew R et al : Pat terns of recurrence of rectal cancer after potentially curative surgery. Cancer $52: 1317-1329,1983$

10）稲葉征四郎, 田中承男, 土屋邦之ほか：大腸癌術後 再発に関する臨床的・病理学的検討一とくに再発 予知に関する数量化の試みについて一，日消外会 誌 $19: 2266-2271,1986$

11）五十嵐正広, 勝又伴栄, 内藤吉隆ほか：内視鏡診断 からみた大腸 $\mathrm{pm}$ 澏の特徵。胃と腸 $27 ： 1283$ 1291, 1992

12）角田明良, 河村正敏, 吉沢太人ほか：大腸 $\mathrm{pm}$ 癌の 臨床病理学的検討. 日本大腸肛門病会誌 $45: 346$ $-351,1992$

13）貞廣荘太郎, 野登 隆, 木村富彦ほ加：大腸の手術 中の長さと切除困定後の長さの比較. 日本大腸肛 閒病会誌 $48: 635-638,1995$

14）猪野 満, 田中隆夫, 武内 俊ほか: 大腸 $\mathrm{pm}$ 癌の 臨床病理的検討. 日本大腸肛門病会誌 $45: 341-$ 345,1992

15）横山善文,伊藤 誠, 金森俊成ほか：X 線診断から みた大腸 $\mathrm{pm}$ 癌の特徵. 胃と腸 $27: 1269-1282$, 1992

16）神野正博, 黒坂慶幸, 小坂健夫ほか：大腸癌腫瘍形 態よりみた血行性転移の検討一特に pm 層穿破形 態よりの検討一. 日外会誌 $93: 139-143,1992$ 


\title{
Image Analyzer Studies on Lymph Node and Hematogenous Metastases in Relation to Growth Appearance and Degree of Invasion in Patients with Colorectal Cancer Invading the Muscularis Propria
}

\author{
Sotaro Sadahiro, Masaya Mukai, Hideki Ishida, Nobuhiro Tokunaga, \\ Tomihiko Kimura, Toshiyuki Suzuki, Hirotada Iwase, \\ Kenji Ishikawa, Tomoo Tajima and Toshio Mitomi \\ Department of Surgery II, Tokai University School of Medicine
}

To ascertain the risk factors of metastasis, 102 patients with colorectal cancer invasing the muscularis propria were examined in terms of growth appearance and degree of invasion with an image analyzer. Type 1 tumors were larger in diamter in the mucosa and in overall tumor area than type 2 tumors. The deeper the invasion, the larger were the diameter and area of the tumor in the muscularis propria, but there was no relationship between the degree of invasion and either the tumor diameter or area in the mucosa. Thus no relationship was recognized between tumor diameter and degree of invasion in patients with colorectal cancer invading the muscularis propria. Although the presence or absence of metastasis to lymph node had no relation to the growth appearance and tumor area in the muscularis propria, the tumor area in the muscularis propria was usually small in patients with hematogenous metastasis $(\mathrm{p}=$ $0.018)$ and the ratio of the tumor area in the muscularis propria to the overall tumor area was lower $(\mathrm{p}<$ $0.01)$ than in patients without hematogenous metastasis. The frequency of hematogenous metastasis decreased with increasing degree of invasion, but the difference was not significant. These results suggest that it is difficult to predict metastasis from either the growth appearance or the degree of invasion in patients with colorectal cancer invading the muscularis propria. Rather, it is worth noting that the frequency of hematogenous metastasis is higher in patients with mild degree of invasion.

Reprint requests: Sotaro Sadahiro Department of Surgery, Tokai University School of Medicine Bohseidai, Isehara, 259-11 JAPAN 